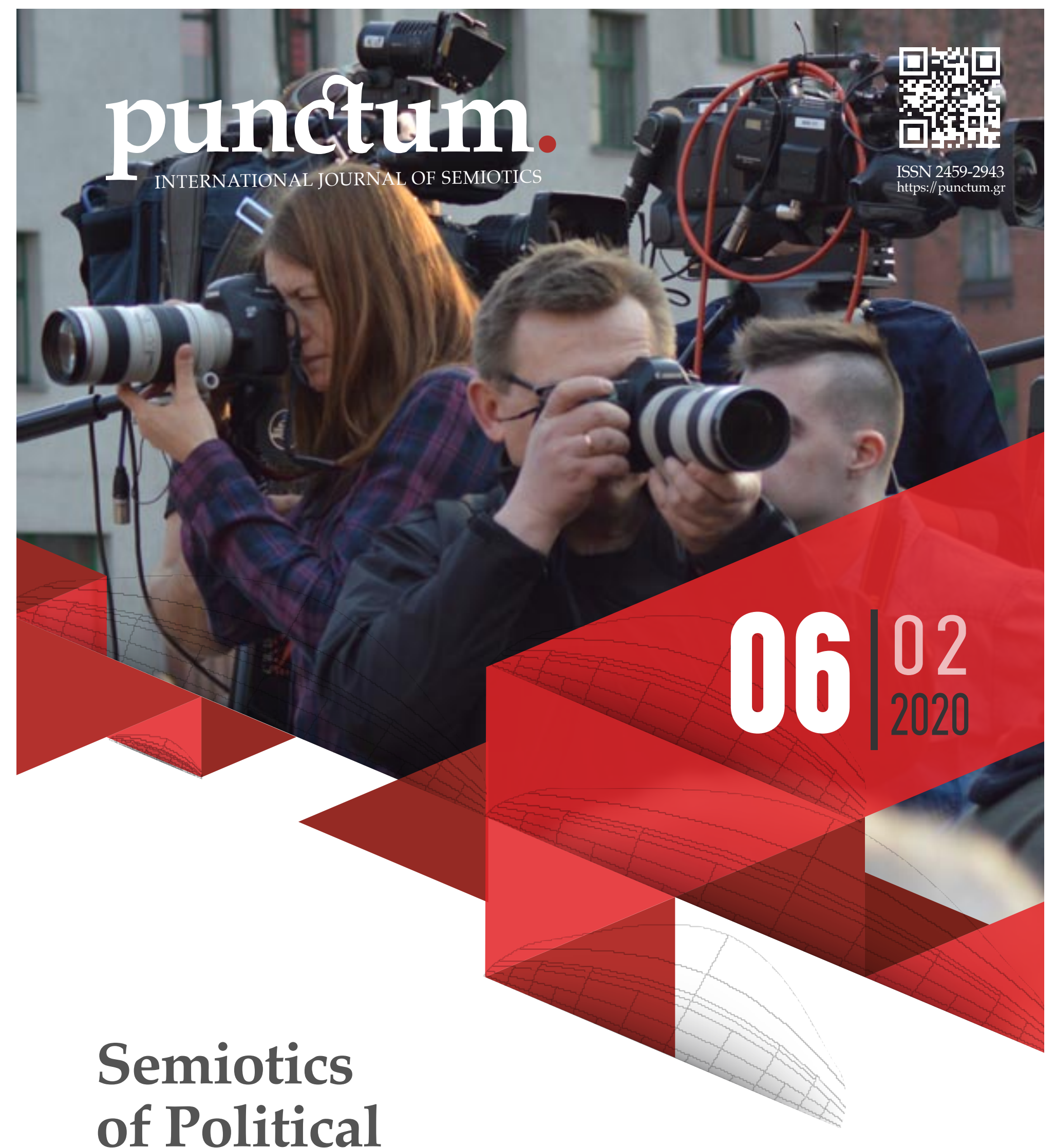

\title{
Communication
}

EDITED BY

Gregory Paschalidis
PUBLISHED BY

THE HELLENIC SEMIOTIC SOCIETY
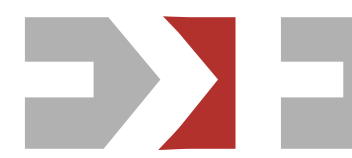


\section{Introduction: Politics as a communicative project}

\section{BY: Gregory Paschalidis}

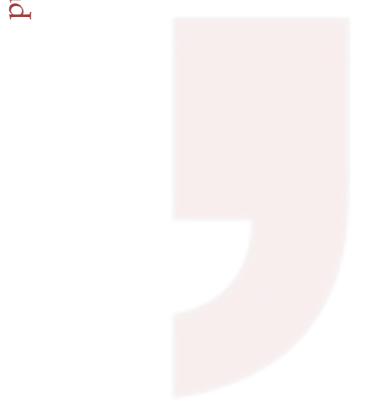

T $\mathrm{n}$ the past few years, there has been a noticeable surge in 1 semiotic engagement with politics. One is tempted to associate it with Laurent Binet's international best-seller The seventh function of language (2017) that offers a satirical yet critically reflexive view of the 1970s linguistic turn and its luminaries. The novel's detective-cum-conspiracy story revolves around the different political sides' bloody scramble to procure a presumably secret semiotic formula for making political language irresistibly persuasive. It would be more accurate, though, to suggest that, just as Umberto Eco's Name of the Rose (1980) - the most successful hitherto merging of semiotic theory and fiction - was an oblique contribution to the linguistic turn's emphasis on the power of language, Binet's novel offers an equally poignant commentary on the 'magic words' of modern-day populism.

Currently, populism's language and ideology are at the epicenter of political theory and political semiotics, including many of this special issue's contributions. Regarding semiotics, this signals a return to its roots since the concern with populism marks postwar semiotics' very beginning. Populist politician Pierre Poujade's discourse is the most recurrent and exten-

ARTICLE INFO:

\begin{tabular}{l}
\hline Volume: 06 \\
\hline Issue: 01 \\
\hline Winter 2020 \\
\hline ISSN: 2459-2943 \\
\hline DOI: 10.18680/hss.2020.0018 \\
\hline Pages: 5-9 \\
\hline Lic.: CC BY-NC-ND 4.0 \\
\hline
\end{tabular}
sively analyzed topic in Barthes' Mythologies. ${ }^{1}$ In the same collection, moreover, Barthes' essay on the candidates' photo-portraits for the French legislative elections of January 1956 makes the latter the first electoral campaign to have attracted semiotic commentary.

\footnotetext{
${ }^{1}$ Unfortunately, Hanna Arendt's selection of Barthes' essays comprising the English translation of Mythologies excludes those dealing specifically with Poujade's language.
} 
Barthes' early forays into political discourse and communication had no noticeable impact. Mythologies' critical project mainly inspired an endless series of 'demystificatory' takes at popular culture artifacts - duly denounced by Barthes as a stereotypical "mythological doxa" (Barthes 1977: 166) - instead of the elaboration of fully-fledged political semiotics. Unsurprisingly, in the late 1980s, Pertti Ahonen asserted that "practically no body of literature on the semiotics of politics exists" (Ahonen 1990: 399).

Political semiotics came to age in the 1990s, this time due to its engagement with nationalism. The crucial turning point was the paradigm change in nationalism studies initiated by the work of Benedict Anderson (1983), Eric Hobsbawm and Terence Ranger (1983), Ernst Gellner (1983), and Pierre Nora (1984-92). Following a rigorously constructivist perspective, the new paradigm entailed reconceptualizing nationhood and national identity as products of symbolic processes and artifacts, communication media, and commemoration rituals. This expansive new research horizon took on a new urgency in the post-Cold War and post-Maastricht Treaty renaissance of European nationalism. Responding to this challenge, semiotic research focused, among others, on national identities (Hedetoft 1995), stamps (Scott 1995), national hero biographies (Makolkin 1992), and national flags and hymns (Cerulo 1995).

Since the beginning of the 21st century, the political communication field is a state of comprehensive reconstruction. On the one hand, the political landscape is in flux as long-established political agents (e.g., traditional political parties, the European Union) face a legitimation crisis and are challenged by the rise of new political parties and ideologies, NGOs, and social movements. On the other hand, the dramatic decline of heritage media and the rise of the distinctly multi-voiced, interactive, and participative social media has given a new semiotic dynamic to the communication flows between the government, the political agents, and the citizenry. In the new media ecosystem, traditional gatekeeping is mostly irrelevant, polarization and 'echo chambers' endemic, and twits and internet memes have a far greater impact than front-page titles, television interviews, or press conferences. Professional spin doctors and communication consultants operate on a par - and quite often as a pair - with massive troops of mediasavvy activists and volunteers. More often than not, moreover, semiotics is politically weaponized by marketing and branding experts.

the basic premise of our invitation to investigate the changing semiotic nature of contemporary politics is Pertti ahonen's assertion that politics is always "a communicative enterprise" and "a result of communicative actions." (Volli 2003: 2924, 2922). and this is true not only in modern mass societies, but also "in societies where mass communication is not so important because the media are not well developed, or the majority of the people are not involved in political action" (ibid: 2924). based on ahonen's comprehensive semiotization of politics, political communication can be seen to comprise a highly diverse range of texts and artifacts, rituals and symbolic practices, 
Introduction: Politics as a communicative project

communication media and modes through which power is legitimized or challenged, political discourse is articulated, validated and disseminated, political identities and communities are configured or transfigured, and power effects and relations are produced or resisted. This semiotizing perspective is clearly distant from the prevailing instrumentalist view of political communication as a supportive, supplementary and quite often ambivalent appendage to 'real politics.' Most importantly, by being consistent with Greimas' classical determination of semiotics as a metalanguage of social sciences (Greimas 1990), that focuses on their discursive construction and communication, it unifies the political's semiotic investigation by effectively bridging the semiotics of political discourse with that of political science, i.e., the political sign system (faire politique) with the scientific sign system (faire scientifique).

In her recent overview of the field, Giovanna Consenza (2018: 8) observes that semiotics' analytical bias, while fostering numerous individual case studies, has so far prevented the appearance of a systematic treatment of political communication semiotics. But, perhaps there is no real need for anything like that. As she astutely adds, the basic semiotic concepts and methodologies required to analyze any text type are already available in many relevant publications.

The contributions making up this special issue on the Semiotics of Political Communication can be grouped into four distinct subject areas. The first concerns political identity building. Specifically, Sebastian Moreno Barreneche explores the semiotic logic governing the collective identities' construction in the political domain. The author highlights the importance of the space of indetermination existing between antagonistic political identities in sustaining the communicative rationality of the democratic public sphere. Johan Fornas, on the other hand, investigates how European identity is configured through political symbols and narratives. Synthesizing findings from his previous research on this subject and combining semiotics with the critical hermeneutics of culture, the author identifies the three dominant thematic tropes around which these symbols and narratives are crystallized.

The second group of contributions addresses the question of populism. Carlo Berti and Chiara Polli focus on right-wing populist satire, as exemplified in the work of the popular Italian cartoonist Ghisberto. Through a meticulous analysis of his 2020 Populist Diary, the authors demonstrate how his powerfully visceral satirical cartoons transcode populist ideology's essential ingredients, all the while clarifying why satirical cartoons have become the communicational form of choice for Italian populist leaders. Ulf Hedetoft explores populism as a fantasy variant of nationalism, prioritizing identity, charisma, and a moral definition of the citizenry over economic rationality, national interest, and citizenry's legal definition. Populism's paradoxes and contradictions, he argues, not least of which is the conflict between its idyllic vision and its authoritarian reality, justify its description as a collective fantasia of despair. Eric Landowski, finally, outlines 
a typology of political regimes based on their different interactional regimes. Based on this, he explains populism's success in terms of the uniquely intimate and sensual relationship that populist leaders establish with their followers.

The third and largest group of contributions deals with the analysis of political discourse. Most of them focus on the interplay between media and political discourse and highlight the semiotic force of political communication's non-verbal dimension. Specifically, Mariano Fernández and Gastón Cingolani conduct a comparative analysis of the media strategies employed by the former Argentinian Presidents, Cristina Fernández de Kirchner and Mauricio Macri. The authors demonstrate how these media strategies configure entirely different political scenes of representation and conflicting notions of the citizenry and political participation. Evangelos Kourdis, on the other hand, examines how European media, siding with European authorities' attitude, semiotically depreciated the left-wing Greek government of SYRIZA in 2015. Using a corpus of newspaper photos and cartoons, the author demonstrates the politically normative and normalizing deployment of the codes of touch, gesture, clothing, and distance. Iván Facundo Rubinstein and Laura Nallely Hernández Nieto examine four comics commissioned by Mexican state institutions to serve particular public interest campaigns. Deploying a specially designed analytical framework, the authors demonstrate how the comics' verbo-visual language functions instead as governmental propaganda. Finally, Gabrielle Rava examines the divergent identity narratives promoted by different parts of contemporary post-conflict yet still divided Belfast. On the one hand, the official narrative's city rebranding semiotic strategies of a postmodern memoryless nonlocality; on the other, the nationalist quarter Gaeltacht's history-infused use of murals and the Irish language.

The fourth and final group of contributions deals with political oratory and rhetoric. Bernard Lamizet offers a systematic account of the semiotic articulation of power's discourse around four instances: the political enunciation, the discursive expression of the actor's identity, the political specificity of power's performativity, and the discourse's political unconscious. Employing this framework to analyze French President E. Macron's speech during the recent Congress of the Association of France's Mayors (November 19, 2019), the author brings forth the unique performative force of political discourse. The rhetoric of another European leader, Danish Prime Minister Mette Frederiksen, is Lisa Villadsen's object of study. Employing the analytical tools of a conceptually oriented rhetorical criticism, the author examines Frederiksen's framing of corona-safe behavior guidelines evolved to culminate in the concept of 'civic-mindedness': a widely resonant merging of Danish nationalism and Social Democratic ideology. Finally, Matteo Modena investigates how Malthus's overpopulation concept emigrated from scientific demographic debate to public controversy and its diverse recent political uses. The author pays particular attention to the concept's political weaponization in the context of contemporary anti-immigration and eco-fascist ideology. 
Historically, semiotics has been repeatedly accused of being apolitical, and perhaps for a good reason. Like many other recent studies, this special issue's contributions leave no doubt about semiotics' strengths and relevance for contemporary political communication research.

\section{References}

Anderson, Benedict 1983. Imaginary Communities. London: Verso.

Ahonen, Pertti 1990. Meaning, subject, and reality as semiotic foci of political research. In: Thomas A. Sebeok and Jean Umiker-Sebeok (eds.) The Semiotic Web 1989. Berlin: Mouton De Gruyter, 399-446.

Barthes, Roland 1957. Mythologies. Paris: Seuil.

Billing, Michael 1995. Banal Nationalism. London: Sage.

Binet, Laurent 2017 [2015]. The seventh function of language. Trans. S. Taylor. New York: Farrar, Strauss, and Giroux.

Cerulo, Karen 1995. Identity Designs. New Brunswick, NJ: Rutgers University Press. Cosenza, Gabriella 2018. Semiotica e comunicazione politica. Bari/ Roma: Laterza.

Gellner, Ernst 1983. Nations and Nationalism. London: Blackwell.

Greimas, A. J. 1990 [1976]. Social sciences: A semiotic view. Trans. P. Perron and F. H. Collins. Minneapolis: University of Minnesota Press.

Hedetoft, Ulf 1995. Signs of Nations. Studies in the political semiotics of self and Other in contemporary European Nationalism. Dartmouth: Aldershot.

Hobsbawm, Eric and Terence Ranger 1983. The Invention of Tradition. Cambridge: Cambridge University Press.

Makolkin, Anna 1992. Name, hero, icon: semiotics of nationalism through heroic biography. Berlin: Walter de Gruyter.

Nora, Pierre 1984-92. Les lieux de memoire, vol. I-III. Paris: Gallimard.

Scott, David 1995. European Stamp Design: A semiotic approach to designing messages. London: Academy editions.

Volli, Ugo 2003. Semiotic aspects of political science: Political semiotics. In: Roland Posner et al. (eds.) Semiotik/Semiotics, vol. III. Berlin: Walter de Gruyter, 2919-26.

AUTHOR

Gregory Paschalidis Professor of Cultural Studies at the School of Journalism and Mass Communications, Aristotle University of Thessaloniki, Greece. 